ASPECTS. Series: Neurology and Neurobiology. Edited by Earl Usdin, Arvid Carlsson, Annica Dahlstrom and Jorgen Engel. Published by Alan R. Liss. 260 pages. $\$ 119 \mathrm{Cdn}$. approx.

CLINICAL ANESTHESIA IN NEUROSURGERY. 1984. Edited by Elizabeth A.M. Frost. Published by Butterworths. 480 pages. $\$ 62 \mathrm{Cdn}$. approx.

CLINICAL ELECTROMYOGRAPHY: NERVE CONDUCTION STUDIES. 1984. By Shin J. Oh. Published by University Park Press. 544 pages. $\$ 61 \mathrm{Cdn}$. approx.

CONTEMPORARY NEUROLOGY. 1984. Edited by M.J.G. Harrison. Published by Butterworths. 641 pages. $\$ 75 \mathrm{Cdn}$. approx.

DEVELOPMENT OF NERVE CELLS AND THEIR CONNECTIONS. 1984. By W.G. Hopkins and M.C. Brown. Published by Cambridge University Press. 137 pages. $\$ 37 \mathrm{Cdn}$. approx. (hardcover), \$17 Cdn. approx. (paperback).

FROM NEURON TO BRAIN. 2nd Edition. By Stephen W. Kuffler, John G. Nicholls and A. Robert Martin. Published by Sinauer Associates, Inc. 651 pages. $\$ 38 \mathrm{Cdn}$. approx.

INFECTIOUS DISEASES OF THE CENTRAL NERVOUS SYSTEM. 1984. Edited by Richard A. Thompson and John R. Green. Published by Spectrum Publication Inc. 256 pages. $\$ 50$ Cdn. approx.

JAMIESON'S FIRST NOTEBOOK OF HEAD INJURY. Third Edition. By Brian North. Published by Butterworths. 116 pages. $\$ 12 \mathrm{Cdn}$. approx.

METHODS FOR NEURONAL RECORDING IN CONSCIOUS ANIMALS. Ibro Handbook Series: Methods in the Neurosciences, Volume 4. By Roger Lemon. Published by John Wiley \& Sons, Inc. 162 pages. $\$ 50 \mathrm{Cdn}$. approx. (hardcover), $\$ 25$ Cdn. approx. (paperback).

METHODS FOR PREPARATION OF MEDIA, SUPPLEMENTS AND SUBSTRATA FOR SERUM - FREE ANIMAL
CELL CULTURE. Series: Cell Culture Methods for Molecular and Cell Biology. Edited by David W. Barnes, David A. Sirbasku and Gordon H. Sato. Published by Alan R. Liss. 378 pages. $\$ 62$ Cdn. approx.

METHODS FOR SERUM - FREE CULTURE OF NEURONAL AND LYMPHOID CELLS. Series: Cell Culture Methods for Molecular and Cell Biology. Edited by David W. Barnes, David A. Sirbasku and Gordon H. Sato. Published by Alan R. Liss. 280 pages. $\$ 49 \mathrm{Cdn}$. approx.

NEURAL ORIGIN OF RHYTHMIC MOVEMENTS. 1984. Edited by Alan Roberts and Barry L. Roberts. Published by Cambridge University Press. 503 pages. $\$ 93 \mathrm{Cdn}$. approx.

PERIPHERAL NERVE DISORDERS. NEUROLOGY 4. Edited by Arthur K. Asbury and R.W. Gilliatt. Published by Butterworths. 339 pages.

PROGRESSIVE SPINAL MUSCULAR ATROPHIES. Edited by I. Gamstorp and H.B. Sarnat. Published by Raven Press. 243 pages. $\$ 28 \mathrm{Cdn}$. approx.

SENILE DEMENTIA: OUTLOOK FOR THE FUTURE. Series: Modern Aging Research, Vol. 5, 1984. Edited by Jean Wertheimer and Maurice Marois. Published by Alan R. Liss. 562 pages. $\$ 85 \mathrm{Cdn}$. approx.

STRESS, IMMUNITY AND AGING. Immunology Series, Volume 24. Edited by Edwin L. Cooper. Published by Marcel Dekker Inc. 336 pages. \$75 Cdn. approx.

THE EPILEPSIES: A CRITICAL REVIEW. 1984. By Robert B. Aird, Richard L. Masland and Dixon M. Woodbury. Published by Raven Press. 320 pages. $\$ 65 \mathrm{Cdn}$. approx.

THE HYPOTHALAMUS OF THE GUINEA PIG: A Cytoarchitectonic Atlas. 1984. By Ruth Bleier. Published by the University of Wisconsin Press. 134 pages. \$62 Cdn. approx.

THE NEUROMUSCULAR JUNCTION. Edited by Roger A. Brumback and Jeffery Gerst. Published by Futura Publishing Company. 354 pages. $\$ 49 \mathrm{Cdn}$. approx.

\title{
Correspondence
}

\section{INTERACTIONS OF ANTIEPILEPTIC DRUGS}

\section{To The Editor:}

Readers of Albright and Bruni's article, Pharmacokinetic Interactions of Antiepileptic Drugs (1984; Vol. 11: 247-251), should be made aware of two other important drug interactions involving this group of drugs.

We showed that cimetidine decreased the clearance of phenytoin (Bartle et al., 1983). Although the interindividual range of decreases was considered, with reductions up to $25 \%$ after $1200 \mathrm{mg}$ cimetidine a day and up to $33 \%$ after $2400 \mathrm{mg}$ a day, in all subjects studied there was a greater reduction in clearance with $2400 \mathrm{mg}$ a day than with $1200 \mathrm{mg}$ a day. Hetzel et al. (1981) showed that cimetidine increased plasma levels of phenytoin in four epileptic patients, one of whom became clinically toxic. $\mathrm{H}_{2}$-antagonists, in general, and cimetidine, in particular, are thought to be the most widely prescribed drugs in the world.
Ranitidine is known to have little if any effect on hepatic drug metabolizinag enzymes and thus should be a safe but effective alternative to cimetidine for patients on anticonvulsant drugs.

Erythromycin is thought to inhibit hepatic drug metabolizing enzymes and has been shown to produce carbamazepine toxicity in four young epileptics (Hedrick et al., 1983).

Drug interaction studies and anecdotal reports have mentioned only a few of the many drugs that could potentially interact with the various anticonvulsant drugs. Patients who are having additional drug therapy added to their anticonvolusant regimens should have plasma level monitoring performed more frequently during these periods.

Bartle WR, Walker SE, Shapiro T (1983) Dose-dependent effect of cimetidine on phenytoin kinetics. Clin Pharmacol Therapeut 33: 649-655.

Hetzel DJ, Bochner F, Hallpike JF, Shearman DJC, Hann CS (1981) Cimetidine interaction with phenytoin. Brit Med J 282: 1512 . 
Hedrick R, Williams F, Morin R, Lamb WA, Cate JC (1983) Carbamazepine-erythromycin interaction leading to carbamazepine toxicity in four epileptic children. Ther Drug Monitoring 5: 405-407.

Wm. R. Bartle, Department of Pharmacy, Sunnybrook Medical Centre, University of Toronto Toronto. Ontario M4N 3 M5

\section{Reply From Authors}

We thank Dr. Bartle for the comments on our recent article (Albright and Bruni, 1984). We agree that cimetidine can elevate phenytoin levels through inhibition of hepatic drug metabolizing enzymes. Cimetidine may also elevate plasma levels of other antiepileptic drugs such as the benzodiazepines.

The purpose of our article was to review the most frequently reported and most significant drug interactions of the antiepileptic drugs, rather than to present all the drug interactions reported. Additional drugs that may elevate phenytoin levels include nortriptylene, phenylbutazone, clofibrate, furosamide, imipramine, sulfonamides, propranolol and phenothiazines. Drugs that may lower phenytoin levels include folate, pyridoxine, and diazoxide.

Carbamazepine plasma levels may be elevated with the concomitant use of propoxyphene, erythromysin and triacetyloleandomycin (Dravet et al., 1977) and clinical intoxication may occur.

We agree with Dr. Bartle that when an additional drug is added to the treatment regimen of a patient on antiepileptic drugs closer monitoring of plasma levels is required to detect possible pharmacokinetic drug interactions.

\section{P.S. Albright J. Bruni}

Albright PS, Bruni J (1984) Pharmacokinetic Interactions of antiepileptic drugs. Can J Neur Sci 11: 247-251.

Dravet C, Mesdjian E, Cenraud B, Roger J (1977) Interaction between carbamazepine and triacetyloleandomycin. Lancet 1: 810-811.

\section{CHOLECYSTOKININ HYPOTHESIS OF TOURETTE SYNDROME}

\section{To The Editor:}

The neuropeptides constitute a large proportion of the putative neurotransmitters within the brain. Not surprisingly, peptides are affected in a number of neurological disorders. The etiology of Tourette Syndrome (TS), a juvenile-onset neurological disorder characterized by chronic, fluctuating motor tics and involuntary vocalizations, is unknown, but may involve neostriatal mechanisms. Most evidence exists for a defect in dopamine (DA) neurotransmission, possibly a supersensitivity of DA receptors (Friedhoff, 1982). Treatment with DA receptor blockers, such as haloperidol, leads to clinical improvement in many, but not all, TS patients. These agents have numerous adverse side effects.

The primary defect in TS might be in cholecystokininoctapeptide (CCK) mechanisms. This neuropeptide coexists with DA in mesencephalic neurons projecting to cortical and limbic forebrain regions. By contrast, striatal CCK appears to arise in neurons in the claustrum and/or piriform cortex and amygdala (Meyer et al., 1982). Despite this lack of localization to the same neurons, CCK has a direct effect on DA receptor function in the striatum. The binding of CCK to its receptor leads to a direct decrease in DA receptor number in this brain region (Fuxe et al., 1981). A decreased striatal CCK transmission could lead to an apparent overactivity of DA systems through the loss of such DA receptor modulation. Treatment with a DA receptor blocker would not address such a deficit directly, possibly explaining the lack of efficacy of this agent in some patients. CCK and related peptides appear to have neuroleptic-like activity, both in animal tests (Van Ree et al., 1983) and in humans with neurolepticresistant schizophrenia (Nair et al., 1983). Therefore, we believe that pharmacotherapies designed to increase striatal CCK transmission would lead to more effective treatments for patients with Tourette Syndrome.

Henrik K. Kulmala, Department of Medical \& Surgical Neurology, Texas Tech University Health Sciences Center,

Lubbock, Texas 79430

Sakkubai Naidu,

John F. Kennedy Institute

Baltimore

Friedhoff, $\mathrm{AJ}$ (1982) Receptor maturation in pathogenesis and treatment of Tourette Syndrome. In Friedhoff, A.J., Chase, T.N., eds., Gilles de la Tourette Synbdrome. Advances in Neurology, Vol. 35. Raven Press, New York, pp. 133-140.

Fuxe K, Agnati LF, Köhler C, Kuonen D, Ögren, S-O, Andersson K, Hökfelt $T$ (1981) Characterization of normal and supersensitive dopamine receptors: Effects of ergot drugs and neuropeptides. $J$ Neural Trans 51: 3-37.

Meyer DK, Beinfeld MC, Oertel WH, Brownstein MJ (1982) Origin of the cholecystokinin-containing fibers in the rat caudatoputamen. Science 215: 187-188.

Nair NPV, Bloom DM, Nestoros JN, Schwartz G (1983) Therapeutic efficacy of cholecystokinin in neuroleptic-resistant schizophrenic subjects. Psychopharmacol Bull 19: 134-136.

Van Ree JM, Gaffori O, DeWied D (1983) In rats, the behavioral profile of CCK-8 related peptides resembles that of antipsychotic agents. Eur J Pharmacol 93: 63-78.

\section{ERratum}

In the paper "Spinal Epidural Lipomatosis" published in the August 1984 issue $(1984 ; 11: 383-386)$, the name of one author was inadvertently omitted and wrong initials were used for another. The list of authors for this article should read N.A. Russell, G. Belanger, B.G. Benoit, D.N. Preston, J.E. Latter, D.L. Finestone and G.W. Armstrong. 